\title{
IKLIM MADRASAH: \\ MOTIVASI KERJA GURU DI MADRASAH TSANAWIYAH NEGERI 1 MODEL MATARAM
}

\author{
M. Habib Husnial Pardi \\ Universitas Islam Negeri [UIN] Mataram \\ Email : muhhabib71@uinmataram.ac.id
}

\begin{abstract}
Abstraksi
Artikel ini menjelaskan iklim madrasah, yakni faktor apa saja yang menumbuhkan motivasi kerja guru di Madrasah Tsanawiyah Negeri 1 Model Mataram, Lombok, Nusa Tenggara Barat. Dengan menggunakan pendekatan kualitatif jenis studi kasus, artikel ini menentukan informan dengan dua cara yaitu snowbolling sampling dan key person. Sementara itu, pengumpulan data dilakukan dengan prinsip redundancy of data gathering melalui observasi partisipan (Participan Observation), wawancara mendalam (indepth interview), dokumentasi, dan diskusi terfokus (Focus Group Disscusion). Sedangkan analisis data dilakukan melalui prosedur Cresswel, yakni memvaliditasi keakuratan informasi melalui sistem coding. Penelitian ini menemukan bahwa iklim Madrasah yang sehat ditandai dengan: kepemimpinan yang demokratis, terjalinnya komunikasi dan interaksi terbuka antar personal, dan penetapan tujuan organisasi melalui keputusan bersama. Hal-hal tersebut akan berdampak pada tumbuhnya motivasi kerja guru seperti kedisiplinan yang tinggi, semangat kerja yang maksimal, dan memiliki sikap kompetisi yang sehat. Dengan demikian, motivasi kerja guru akan berdampak pada peningktan mutu pendidikan di Madrasah.
\end{abstract}

Kata Kunci: iklim madrasah, kerja guru, motivasi; madrasah model

\section{Pendahuluan}

Memahami sebuah organisasi termasuk lembaga pendidikan Madrasah dengan berbagai dimensinya, adalah sangat menarik dan menantang. Kebutuhan akan perubahan dan kemampuan beradaptasi menjadi sebuah keniscayaan. Realitas ini menjadikan organisasi harus dinamis, atau dengan bahasa lain organisasi sangat ditentukan oleh kemampuan dalam merespon berbagai perubahan yang akan mempengaruhi faktor internal dan eksternalnya. Salah satu variable internal yang mempengaruhi baik dan buruknya sebuah organisasi adalah iklim organisasi yang bergantung pada karakteristik tertentu dari lingkungan kerja (Tovey et al., 1999'; Cumbey et al., $1998^{2}$ ).

Iklim organisasi merupakan persepsi bersama tentang lingkungan kerja ${ }^{3}$. Definisi lain adalah persepsi dan sikap masyarakat tentang organisasi, baik atau buruk tempat bekerja,

\footnotetext{
${ }^{1}$ Tovey and Adams, 1999. The changing nature of nurses' job satisfaction: an exploration of sources of satisfaction in the 1990s. Journal of Advanced Nursing, 30 (1999)

${ }^{2}$ Cumbey and Alexander, 1998. The relationship of job satisfaction with organizational variables in public health nursing. Journal of Nursing Administration, 28 (1998)

${ }^{3}$ Jones and James, 1979. Psychological climate: dimensions and relationships of individual and aggregate work environment perceptions. Organizational Behavior and Human Performance, 23 (1979),
} 
bersahabat atau tidak bersahabat (Wendell et al., 2004). Iklim organisasi diartikan sebagai persepsi bahwa anggota organisasi memiliki karakteristik yang mendefinisikan dan membedakannya.Penekanan konsep telah ditempatkan pada persepsi yang dibagikan oleh sekelompok subjek tentang mereka lingkungan kerja (Brow Moberg, 1991). Persepsi dapat mengacu pada proses struktural seperti gaya pengawasan, kebijakan organisasi, praktik, prosedur dan lingkungan kerja, antara lain. Ini tentang konsep multidimensi dan, karena ini, telah diklaim bahwa iklim sebuah organisasi merupakan sekelompok properti atau karakteristik lingkungan internal kerja, dirasakan secara langsung atau tidak langsung oleh pekerja dari sebuah organisasi, yang mempengaruhi perilaku pekerja (Martínez, 2001).

Studi pertama tentang iklim organisasi dilakukan sekitar usia 30-an oleh Kurt Lewin, yang menciptakan istilah suasana psikologis yang bertujuan mempelajari iklim sebagai realitas empiris. Lewin, Lippit dan White (1939) merancang percobaan yang memungkinkan mereka untuk mempelajari efek yang jenis tertentu kepemimpinan terkait dengan iklim; mereka menemukan itu untuk jenis kepemimpinan yang berbeda, jenis yang berbeda atmosfer sosial muncul. Dalam literatur penelitian tentang perilaku organisasi, pengertian tentang iklim organisasi terutama didefinisikan dalam istilah berbagi pandangan tentang kebijakan organisasi, praktik dan prosedur (Reichers \& Schneider, 1990). Iklim organisasi mencerminkan apa adanya dilakukan di lingkungan kerja tertentu. Dessler (1993) mengemukakan bahwa dalam istilah a arti kata iklim belum tercapai. Definisi berangkat dari faktor-faktor objektif murni seperti struktur, kebijakan dan regulasi, hingga dipersepsikan faktor subjektif seperti dukungan dan kebaikan. Karena kurangnya konsensus ini, Dessler (1993) mengidentifikasi definisi istilah berdasarkan fokus yang diberikan oleh para ahli di bidangnya.Yang pertama adalah fokus strukturalis oleh Forehand dan Gilmer (1964) yang mendefinisikan iklim sebagai sekelompok karakteristik tetap yang memungkinkan untuk menggambarkan suatu organisasi, membedakannya dari yang lain, dan yang memiliki pengaruh pada perilaku orang-orang yang menyusunnya.

Konsep ini dapat ditelusuri kembali ke beberapa penelitian, misalnya, Lewin et al.(1939) menganalisis hubungan antara gaya kepemimpinan dan iklim;Koffka (1935) berfokus pada "lingkungan perilaku";Lewin (1936) mempelajari "ruang kehidupan";dan Phillips (1996) menyelidiki bagaimana perempuan dan laki-laki memandang iklim organisasi.Beberapa penelitian telah menunjukkan upaya yang dilakukan untuk lebih memahami faktor-faktor yang berkontribusi untuk meningkatkan lingkungan kerja (atau iklim) dan memotivasi semua karyawan, terlepas dari posisi, status dan jenis kelamin mereka, untuk berkomitmen dan menjadi pelaku yang efektif (Clark, 1997; Gershon,2007; Nembhard, 2006).

Iklim organisasi [khususnya] terus-menerus ditantang oleh perubahan yang berdampak pada organisasi saat ini (Nair, 2006).Begitu juga dengan lembaga pendidikan Madrasah sebagai sebuah organisasi tentu akan sangat ditentukan oleh iklim madrasah itu sendiri. Dalam sejarah perkembangan, Madrasah dihadapkan oleh berbagai persoalan dari status lembaga sampai pada kemampuan berkompetisi dengan lembaga pendidikan umum [sekolah]. Perbincangan dikotomi pun menjadi rame dalam beberapa tahun yang lalu. Belakangan Madrasah mulai menggeliat dan merasa percaya diri dengan sebutan Madrasah 
sepadan dengan sekolah ${ }^{4}$. Beratnya beban tugas madrasah oleh al-Nahlawi dalam Mujib dan Jusuf Mudzakir ${ }^{5}$ menyebut setidaknya ada 8 tugas sebagai lembaga pendidikan tidak membuat lembaga pendidikan Islam ini patah semangat tetapi sebaliknya menjadi lebih bersemangat dan trend belakangan ini pendirian lembaga pendidikan madrasah semakin menjamur dan cukup berprestasi [prestasi akademik dan label madrasah unggul atau model].

Selain itu, adanya sebagian orang yang beranggapan sekolah umumlebih bagus dan berkualitas dibanding dengan madrasah.Kurang tertariknya masyarakat untuk memilih lembaga-lembaga pendidikan Islam, sebenarnya bukan karena telah terjadi pergeseran nilai atau ikatan keagamaannya yang mulai memudar, melainkan karena sebagian besar lembaga-lembaga tersebut kurangmenjanjikan masa depan dan kurang responsif terhadap tuntutan dan permintaansaat ini maupun mendatang. Dalam realitas, Nata ${ }^{6}$ mengurai persoalan klasik madrasah adalah ketidakmampuan madrasah mengimbangi dinamika kebutuhan masyarakat akan kualitas pendidikan yang semakin tinggi serta dinamika pendidikan pada umumnya, di mana kondisi tersebut diperparah oleh kebijakan pemerintah sendiri yang masih menganggap madrasah sebagai "anak tiri” dan diperlakukan sebagai sekolah kelas dua.

\footnotetext{
${ }^{4}$ Sumber Undang-Undang Sistem Pendidikan Nasional Nomor 20 Tahun 2003 tentang Sistem Pendidikan Nasional pasal 1 ayat 1. Baca Azyumardi Azra, Pendidikan Islam, Tradisi dan Modernisasi Menuju Milenium Baru, (Jakarta :Logos Wacana Ilmu, 2002).

${ }^{5}$ Mujib, Abdul, Mudzakir,Jusuf, Ilmu Pendidikan Islam, Cet. I, Jakarta: Kencana Prenada Media, 2006, menyebutkan bahwa tugas madrasah sebagai lembaga pendidikan Islam adalah: 1) Merealisasikan pendidikan Islam yang didasarkan atas prinsip pikir, 'aqīda dan tasyrī' yang diarahkan untuk mencapai tujuan pendidikan, 2) Memelihara fitrah anak didik sebagai insan yang mulia, agar ia tak menyimpang dari tujuan Allah Swt menciptakannya, 3) Memberikan kepada anak didik dengan seperangkat peradaban dan kebudayaan Islami, dengan cara mengintegrasikan antara ilmu-ilmu alam, ilmu sosial, ilmu aksasta yang dilandaskan atas ilmu-ilmu agama, sehingga anak didik mampu melibatkan dirinya kepada perkembangan IPTEK, 4) Membersihkan pikiran dan jiwa dari pengaruh subjektifitas (emosi), karena pengaruh zaman dewasa ini lebih mengarah pada penyimpangan fitrah manusiawi, 5) Memberikan wawasan nilai dan moral, serta peradaban manusia yang membawa khazanah pemikiran anak didik menjadi berkembang, 6) Menciptakan suasana kesatuan dan kesamaan antar anak didik, 7) Tugas mengoordinasi dan membenahi kegiatan pendidikan, 8) Menyempurnakan tugas-tugas lembaga pendidikan keluarga masjid dan pesantren.
}

${ }^{6}$ Nata, A. (2010). Manajemen Pendidikan Mengatasi Kelemahan Pendidikan Islam di Indonesia. Jakarta: Kencana. Selanjutnya Nata menjelaskan bahwa Menurut Nata ${ }^{6}$ menyebutkan bahwa tiga akar penyebab buruknya citra madrasah. Pertama, karena pengelolaan madrasah terlalu didominasi oleh kalangan umat Islam tradisional dan konsevatif, mereka cenderung memahami Islam sebagai agama semata-mata, dan karenanya menganggap ilmu pengetahuan dan teknologi sebagai yang bukan urusan Islam, dan karenanya tidak perlu diajarkan kepada masyarakat. Kedua, Karena pendidikan Islam, khususnya madrasah belum masuk ke dalam bagian dari sistem pendidikan. Keadaan ini terasa amat memberatkan, terutama bagi madrasah yang belum memiliki kemampuan memenuhi kebutuhan finansial secara mandiri. Akibat dari kekurangan finansial ini, mereka tidak mampu mengadakan berbagai sarana dan prasarana pendidikan yang diperlukan, tidak mampu membayar gaji guru secara layak, dan tidak mampu melakukan perencanaan, serta tidak dapat menerapkan metode pembelajaran yang lebih variatif dan berbasis pada pembelajaran para siswa. Ketiga, Karena pendidikan Islam, khususnya madrasah belum memiliki visi, misi, dan tujuan yang jelas. Dengan demikian kegiatan madrasah berjalan apa adanya, tanpa arah dan tanpa tujuan yang jelas, serta memiliki program dan target yang hendak dicapai. 
Permasalahan lain yang cukup sering dijumpai di madrasah pada umumnya adalah tentang kurang maksimalnya dalam praktik manajemen. Secara emperis dan teoritis praktik manajemen akan menghasilkan lembaga pendidikan yang sehat dan bermutu. Mengelola sumber daya manusia [tenaga pendidik dan kependidikan] yang beragam menuntut model kepemimpinan yang adaptif agar tercipta motivasi dan semangat kerja yang maksimal. Para guru sebagai pelaku utama guru tentu memiliki peran strategis dalam menentukan mutu pendidikan di sebuah lembaga [organisasi] tersebut. Karena itu, menciptakan iklim organisasi yang sehat merupakan sebuah keniscayaan agar tercipta motivasi kerja guru secara maksimal. Oleh Keith Davis dan John W, Newstrom ${ }^{7}$ menyatakan bahwa "Iklim dapat mempengaruhi motivasi, prestasi, dan kepuasan kerja. Iklim mempengaruhi hal itu dengan membentuk harapan pegawai tentang konsekuensi yang akan timbul dari berbagai tindakan."

Iklim organisasi adalah kualitas lingkungan yang berlangsung secara relatif yang dialami seluruh personil madrasah termasuk guru. Sebuah iklim timbul melalui interaksi dari anggota dan pertukaran perasaan diantara mereka. Iklim organisasi berhubungan dengan hubungan sosial orang-orang yang ada dalam organisasi yang mencakup komunikasi, kerja sama, supervise atau pengendalian, dukungan sejawat, dan kejelasan tugas yang diemban oleh masing-masing pegawai. Iklim organisasi ini juga pada akhirnya akan mempengaruhi motivasi kerja setiap anggota organisasi.Thoha ${ }^{8}$ mengemukakan bahwa "motivasi merupakan salah satu unsur pokok dalam perilaku organisasi." Hubungan antara iklim organisasi dengan motivasi kerja juga didasari atas teori Davis di atas. Sedangkan Soltani ${ }^{9}$ dkk. mengeksplorasi bahwa ada hubungan yang signifikan antara iklim organisasi dan kebutuhan motivasi karyawan. Studi lain mengusulkan bahwa iklim organisasi memiliki efek positif pada kinerja organisasi (Kangis et al., 2000). Iklim organisasi juga memiliki pengaruh utama yang signifikan efektivitas organisasi seperti komitmen organisasi rekan staf dan identitas kolektif ${ }^{10}$. Sebaliknya, Theodore [1997] menjelaskan bahwa lingkungan kerja yang kurang mendukung seperti lingkungan fisik pekerjaan dan hubungan yang kurang serasi antara guru ikut menyebabkan kinerja guru menjadi buruk.

\section{Metode}

Penelitian ini dilakukan di Madrasah Tsanawiyah Negeri 1 Model Mataram. Memahami iklim Madrasah menurut perspektif, asumsi, definisi, ukuran, logika dan bahkan

${ }^{7}$ Davis, Keith \& W. Newstrom, Jhon. (1985). Perilaku dalam Organisasi. Jakarta:Erlangga.

8 Thoha, Miftah.(2002). Perilaku Organisasi. Jakarta: Raja Grafindo Persada.

${ }^{9}$ Soltani, I., Aghahosseini, M., \& Akbari, N. (2014). Employees' perspective on organizational climate and job motivation factors and their relationship with the Blood Transfusion Organization's employees, 2012. International Journal of Academic Research in Business and Social Sciences, 4(1

${ }^{10}$ Yoo, S. J., Huang, W.-H., \& Lee, D. Y. (2012). The impact of employee's perception of organizational climate on their technology acceptance toward e-learning in South Korea. Knowledge Management \& E-Learning: An International Journal (KM\&EL), 4(3), 359-378. Zhang, J., \& Liu, Y. (2010). Organizational climate and its effects on organizational variables: An empirical study. International Journal of Psychological Studies, 2(2) 
teori informan dan pelaku lainnya populer disebut perspektif emik kebalikan dari perspektif etik. Hal ini diyakini bahwa informan merupakan knowledgeable agen, yang tahu apa yang dilakukan dan mengapa melakukannya. Menurut Giddens bahwa orang awam, siapapun mereka disebut social theorist, yang teori-teorinya diterapkan dalam kehidupan mereka sehari-hari ${ }^{11}$.

Penelitian ini menggunakan pendekatan penelitian kualitatif jenis studi kasus yang bersifat "menukik" ke dalam dunia makna dan interpretasi para pelaku tindakan sosial meliputi dunia konseptual, dunia kesadaran, dunia rasionalitas dan berbagai hal yang terkait dengan subjektivitas si pelaku tindakan. Oleh karena itu, apapun yang terpola dari refleksi ide,pikiran, keyakinan dan kebiasaan sehari-hari yang berkaitan dengan prinsif-prinsif manajemen iklim Madrasah dan nilai-nilai religious dan social budaya dari pelaku manajemen itu sendiri, tidak lepas dari makna yang terkonstruksi dari mereka.

Objek penelitian ini adalah segala aktivitas yang terkait dengan iklim organisasi madrasah dan motivasi kerja guru. Untuk memperkaya data penelitian, peneliti menggunakan dua cara dalam menentukan informan yaitu cara snowbolling sampling ${ }^{12}$ dan key person. Data dikumpulkan dengan prinsif redundancy of data gathering ${ }^{13}$ yaitu data dikumpulkan dengan berbagai metode hingga mencapai titik jenuh. Artinya, data baru berhenti diexplore bila sudah tidak ada lagi bias-bias data atau data dinilai sudah cukup memadai melalui observasi partisipan (Participan Observation), metode wawancaramendalam (indepth interview), metode dokumentasi, dan diskusi terfokus (Focus Group Disscusion). ${ }^{14}$ Sedangkan analisis data ${ }^{15}$ melalui prosedur ditawarkan oleh Cresswell $^{16}$ dengan istilah memvaliditasi keakuratn informasi melalui tahap-tahap yaitu terapkan proses coding untuk mendeskripsikan setting, orang-orang, katagori, dan tema-tema yang akan dianalisis, tunjukkan bagaimana tema-tema itu dirangkaian kembali dalam bentuk narasi/laporan penelitian, dan menginterpretasi atau memaknai data [kesimpulan].

\section{Hasil dan Pembahasan}

\section{Iklim Madrasah}

Lembaga Pendidikan Islam Madrasah merupakan salah satu bentuk organisasi [Gitosudarmo, dkk,1977, Sutarto, 1995, Usman, 2010, Schein, 1982, Muhammad, 2014] yang memiliki berbagai unsur, antara lain; kepala madrasah, guru, siswa, tenaga administrasi dan lain-lain. Dan setiap individu yang ada dalam organisasi memiliki peran, nilai, prinsip dan motif yang berbeda-beda.Semua unsur tersebut saling berinteraksi dan mempengaruhi satu

\footnotetext{
${ }^{11}$ Giddens, Anthony (1984), The Constitution of Society; Outline of the Theory of Structuration (Berkley: University of California Press), hlm. xxxiii

${ }^{12}$ Burhan Bungin, (2008), Penelitian Kualitatif.....Op.cit, hlm, 77

${ }^{13}$ Robert E. Stake, Studi Kasus dalam Denzin \& Lincoln (2009), Handbook Of Qulaitatif Research (trj), (Yogyakarta: Pustka Pelajar), hlm. 307

${ }^{14}$ Mujdia Raharjo (2011), Metode Pengumpulan Data Penelitian Kualitatif....Op.cit,

${ }^{15}$ Burhan Bungin, (2008), Penelitian Kualitatif,......Op.cit, hlm. 153-154

${ }^{16}$ John W. Creswell (2010), Desain penelitian; ..Op.cit, hlm. 276-283
} 
sama lain. Prosessaling berinteraksi dan mempengaruhi kemudian membentuk suasanaatau iklim organisasi ${ }^{17}$.Untuk memahami iklim Madrasah sebagai sebuah organisasi, bisa diamati dan dipahami indikator-indikator ${ }^{18}$ antara lain; pertamapengendalian. Implementasi kegiatan proses pendidikan di lembaga pendidikan, fungsi pengendalian terhadap semua program kerja madrasah yang ditetapkan sebelumnya melalui rapat kerja merupakan dimensi leadership dalam hal ini Kepala Madrasah. Kegiatan pengendalian dilaksanakan melalui dua cara yaitu pengendalian langsung oleh kepala Madrasah dan pengendalian tidak langsung dimana wewenang dan tugas tersebut didelegasikan ke Wakamadnya sesuai bidang dan wilayah kerja.Bahasa lain dari pengendalian adalah kepala Madrasah sebagai pemimpin melaksanakan pemantauan baik secara langsung maupun tidak langsung terhadap segala aktivitas bawahan dalam melaksanakan segala progam yang telah dikonstruksi dan ditetapkan dalam rencana kerja.

Keduakepemimpinan. Sekecil apapun organisasi maka keberadaan pemimpin dengan segala sifat dan karakter kepemimpinannya merupakan sebuah keniscayaan. Begitu juga di lokasi penelitian bahwa kepemimpinan melekat pada figure Kepala Madrasah. Secara umum, kepemimpinan kepala Madrasah di lokasi penelitian dari periode ke periode selanjutnya terdapat dua pola yang dilaksakan yaitu melanjutkan visi misi kepala Madrasah sebelumnya dan merencanakan dan melakasanakan program-program kerja baru sesuai dengan kebutuhan dan tuntutan zaman. Ketigakomunikasi dan intraksi. Dalam melaksanakan berbagai program kerja yang dibreakdown dari visi dan misi Madrasah, proses komunikasi dan intraksi adalah sebuah media dalam mempermudah implementasi program kerja. Tanpa komunikasi dan intraksi yang baik maka semua program kerja Madrasah tidak akan berjalan sesuai harapan dan rencana yang sudah ditetapkan.

Karena itu, suatu iklim organisasi Madrasah akan tercipta dengan baik dan kondusif apabila proses komunikasi dan intraksi antar pimpinan dan bawahan dan bawahaan dengan lainnya bisa tercipta dalam hubungan penuh kekeluargaan. Komunikasi dan intraksi di lokasi penelitian yang dimaksud adalah kepala Madrasah dan wakil kepala dan para guru serta peserta dan stakeholder (wali murid). Relasi yang harmonis antara pegawai/guru dengan pegawai/guru dan pegawai/guru (bawahan) dengan pimpinannya-Kepala Madrasah, misalnya dapat saling bekerja sama dalam menyelesaikan pekerjaan dan dapat saling menyesuaikan diri dengan lingkungan di tempat kerja. Keempatpenetapan tujuan. Idealnya setiap satuan pendidikan begitu juga Madrasah pada umumnya telah merumuskan tujuan yang ingin dicapai bersama. Tujuan tersebut merupakan penjabaran dari visi dan misi Madrasah. Dalam menetapkan visi dan misi serta tujuan di lokasi penelitian dilakukan melalui proses pertemuan (rapat) antara kepala Madrasah dengan bawahan. Karena itu iklim organisasi yang baik dan kondusif ditandai oleh suatu lingkungan madrasah, baik lingkungan kerja yang dapat dinilai secara langsung atau tidak langsung, yang tercipta akibat adanya pengendalian, motivasi, komunikasi dan interaksi, kepemimpinan, pengambilan keputusan, dan penetapan tujuan.

\footnotetext{
${ }^{17}$ Baca Indrawidjaja, Adam. (1986). Perilaku Organisasi. Bandung: Sinar BaruAlgesindo

${ }^{18}$ Davis, Keith \& W. Newstrom, Jhon. (1985). Perilaku dalam Organisasi. Jakarta:Erlangga.
} 
Hasil penelitian menunjukan bahwa gambaran umum iklim organisasi madrasah berdasarkan data temuan mendeksripsikan bahwa bahwa iklim Madrasah bisa dikatagorikan sangat baik. Indicator komunikasi dan interaksi Salah satu yang menentukan baik buruknya iklim organisasi adalah komunikasi dan interaksi, yang nantinya akan melahirkan suatu kerjasama dan sebagai sarana transformasi, yang mampu membantu guru dalam mengembangkan dan meningkatkan kinerja. Indikator ini juga seperti yang terdapat dalam pengertian iklim organisasi yang dikemukakan oleh Hoy dan Miskel [dalam A. Nurdin, 2005], bahwa "suatu iklim timbul melalui interaksi dari para anggota dan pertukaran perasaan di antara mereka". Begitu juga yang dikemukakan Davis dan Newstrom [1996] bahwa organisasi dapat terbentuk oleh sejumlah unsur, salah satunya yaitu komunikasi vertikalhorizontal, yang menjadi salah satu unsur yang dapat membentuk iklim organisasi yang menyenangkan.

Komunikasi dan interaksi sebagai indikator dari iklim organisasi madrasah berada dalam kategori sangat baik. Komunikasi dan interaksi yang terjalin selain intern madrasah juga terjalin dengan ektern madrasah. Yakni dengan orang tua siswa dan lingkungan masyarakat. Komunikasi dan interaksi dengan semua penghuni madrasah dirasa sudah sangat baik serta dapat membantu guru, selain dapat memberikan kenyamanan bekerja bagi guru. Seperti yang dikemukan oleh Theodore [1996], bahwa: "lingkungan kerja yang kurang mendukung seperti hubungan kurang serasi antar guru ikut menyebabkan kinerja menjadi buruk". Hal ini berarti komunikasi dan interaksi yang terjalin baik dengan semua warga madrasah akan dapat mendukung dan memungkinkan segala aktivitas guru terlaksana dengan baik.

Selanjutnya Pengendalian, Stephen P. Robbins [2009] mengemukakan bahwa pengendalian adalah kegiatan pemantauan kegiatan guna meyakinkan bahwa kegiatan tersebut diselesaikan seperti yang direncanakan. Pengendalian sebagai indikator dari iklim organisasi berada dalam kategori sangat baik. Dengan memenuhi kriteria-kriteria pemantauan yang dilakukan langsung oleh pimpinan terhadap bawahannya melalui berbagai cara, baik melalui pemberian pengarahan ataupun melalui bimbingan yang diberikan pimpinan terhadap bawahannya.

Sementara itu, dalam hal KepemimpinanSebagaimana yang dikemukakan oleh Davis dan Newstorm ${ }^{19}$ bahwa salah satu unsur yang dapat membentuk iklim organisasi yang menyenangkan adalah kualitas kepemimpinan. Pimpinan yang berkualitas yaitu pimpinan yang profesional yang memiliki keterampilan human ralation, technical dan konceptual. Kepemimpinan di Madrasah berada dalam kategori sangat baik. Hal ini berarti tingkat kepemimpinan di lokasi penelitian dalam kategori sangat baik. Hal ini ditandai dengan kepemimpinan yang demokratis, dimana kepala madrasah lebih mementingkan kepentingan bersama dan selalu membicarakan dengan warga madrasah sebelum dibuat suatu kebijakan baru, serta selalu membicarakan kesempatan pada seluruh warga madrasah berkreasi dan

\footnotetext{
${ }^{19}$ Davis, Keith \& W. Newstrom, Jhon. (1985). Perilaku dalam Organisasi. Jakarta:Erlangga
} 
berinovasi. Selain itu interaksi yang terjalin antara kepala madrasah dan para guru dapat mengembangkan inisiatif para guru.

Kepala madrasah juga memberikan kebebasan penuh pada para guru dalam melaksanakan tugas. Faktor kepemimpinan sangat berpengaruh besar terhadap iklim organisasi yang terbentuk karena akan sangat menentukan strukturorganisasi, kebijakan serta praktek manajemen, dimana poin-poin tersebut merupakan unsur yang akan menentukan suatu iklim organisasi ${ }^{20}$. Diungkapkan bahwa makin tinggi tingkat penstrukturan suatu organisasi maka iklim organisasi akan terasa semakin kaku, tertutup dan penuh ancaman. Sebaliknya iklim organisasi akan menjadi menyenangkan dan semakin kondusif ketika makin besar otonomi dan kebebasan yang diperoleh para guru dalam bekerja. Hal ini berarti, kepemimpinan profesional yang demokratis yang memiliki keterampilan manajerial merupakan kepemimpinan yang mampu menciptakan iklim organisasi yang baik dan menyenangkan.

Sedangkan pengambilan keputusanmenurut Tekrick dan Nancy Da Silva ${ }^{21}$ mengemukakan bahwa bila dalam suatu organisasi semua pengambilan keputusan dilakukan oleh satu orang yang berada di pucuk kepemimpinan, iklim organisasi tersebut adalah iklim kerja dengan tanggung jawab rendah. Hal ini berarti, proses pengambilan keputusan turut menentukan iklim organisasi yang terbentuk. Proses pengambilan keputusan sebagai indikator dari iklim organisasi madrasah dilaksanakan secara demokratis musyawarah mufakat. Dalam proses pengambilan keputusan para guru dan pegawai yang berkepentingan akan diikutsertakan sehingga apapun keputusan yang telah ditetapkan merupakan tanggung jawab bersama.

Tahapan-tahapan dalam proses pengambilan keputusan juga dilalui dengan menganalisis masalah sebelum membuat suatu keputusan, selain itu masukan-masukan dari para guru dan staf juga diikutsertakan yang kemudian akan dijadikan sebagai salah satu alternatif pemecahan. Dari proses pengambilan keputusan kemudian dihasilkan suatu keputusan bersama yang akan dilaksanakan dengan baik oleh seluruh warga madrasah.

Untuk kegiatan penetapan tujuan ditemukan bahwa ada proses kerja sama, dengan itu dapat dilihat seperti apa iklim organisasi yang terbentuk di dalamnya, karena dari proses dan cara penetapatan tujuan akan dihasilkan suatu tujuan yang turut akan menghasilkan suatu tujuan yang turut menentukan iklim organisasi. Penetapan tujuan di Madrasah berjalan dengan baik dengan menerapakan azaz keadilan dan kebersamaan. Ini berarti bahwa tingkat komunikasi dan interaksi yang ada di lokasi penelitian berada dalam kategori sangat baik. Dalam penetapan tujuan, tujuan dirumuskan dan ditetapkan bersama. Disamping itu setiap kegiatan yang diselenggarakan madrasah dilaksanakan dengan baik sehingga tercapai tujuan yang diharapkan. Dari tujuan yang sudah ditetapkan, para guru memahami dengan baik apa

\footnotetext{
${ }^{20}$ Steers, Richard M. (1985). Efektifivas Organisasi. Cetakan Kedua. Jakarta:Erlangga

${ }^{21}$ Nurdin, Asep (2005). Kontribusi Kompensasi dan Iklim Organisasi Sekolah terhadap Kinerja Guru (Kajian Terhadap Guru SMP Di Kabupaten Bandung). Tesis (Tidak Dipublikasikan). Bandung. PPS UPI.
} 
yang pimpinan inginkan dari pelaksanaan tugas-tugas mereka sebagai pengajar dan melaksanakannya dengan sangat baik.

\section{Motivasi Kerja Guru}

Untuk memahami motivasi kerja guru secara terukur maka bisa diamati dan dipahami beberapa indikator antara lain; pertama disiplin. Aspek disiplin dalam mengukur motivasi seseorang bisa diamati dari kehadiran tepat waktu, menjalankan tugas dengan baik, mentaati peraturan yang berlaku, menerima sanksi atas kelalaian yang dilakukan saat bekerja. Artinya, kedisiplinan berorientasi pada kesanggupan pegawai untuk mentaati segala ketentuanketentuan yang berlaku di madrasah.Terciptanya kesadaran diri tuk berbuat disiplin juga disebabkan oleh akibat dari repleksi kepemimpinan kepala Madrasah. Kedua semangat kerja. Adanya semangat kerja dalam melaksanakan tugas dan kewajiban merupakan modal besar menuju keberhasilan. Semua pekerjaan akan terasa ringan dan mudah. Demikian juga dengan data lapangan di lokasi penelitian bahwa rata-rata semangat kerja guru bisa dikatagorikan cukup baik. Semangat kerja bisa teramati dari keseharian para guru dalam mengerjakan tugas mengajarnya baik pada waktu jam pagi maupun waktu belajar siang. Semangat kerja yang dimiliki oleh mereka ini berdampak pada motivasi para siswa untuk terus bisa mengikuti proses pembelajaran di kelas.

KetigaKompetisi.Kompetisi yang dimaksud dalam penelitian ini adalah semangat dan sikap yang ditunjukkan oleh guru untuk selalu bisa menjadi yang terbaik baik di kalangan teman-teman sejawat maupun teman-teman guru di institusi lain. Sikap ini tercermin dalam melaksanakan kegiatan pembelajaran di kelas. Adanya sikap bersaing sehat ini memberikan pengaruh terhadap hubungan antar teman sejawat dan atasan (pimpinan). Tidak ada yang merasa tersakiti dan istimewakan, semua diperlakukan sama dan akan diberikan penghargaan bagi yang berprestasi. Dengan adanya persaingan yang sehat antara guru sehingga berpengaruh terhadap motivasi kerjanya masing-masing.KeempatKerja Keras. Tuntutan akan semangat kerja keras dalam sebuah organisasi merupakan sebuah keharus terutama bagi organisasi yang berkatagori maju. Data temuan di lokasi penelitian menunjukkan bahwa semangat kerja guru dan pegawai sangat baik. Semua beban dan tugas yang diberikan akan dikerjakan secara maksimal dengan mengerahkan semua kemampuan yang dimiliki. Tugas mengajar dilaksanakan dengan dengan penuh kejujuran, loyalitas dan dedikasi yang tinggi demi organisasi atau lembaga (Madrasah) tempat mereka berkerja.

\section{Pengaruh Iklim Organisasi Terhadap Motivasi Kerja Guru}

Iklim organisasi merupakan suatu bentuk penilaian yang dipersepsikan oleh setiap individu yang ada dalam organisasi. Persepsi akan berbeda-beda pada setiap individu, tergantung pada bagaimana individu memandang suatu organisasi.Iklim organisasi mencakup iklim kerja dan lingkungan kerja. Iklim ini nantinya akan berdampak pada kinerja guru. Baik buruknya iklim organisasi akan berdampak dan berkontribusi terhadap efektif tidaknya kinerja guru, karena iklim organisasi akan mempengaruhi motivasi dan perilaku dalam 
organisasi tersebut. Iklim organisasi dapat mempengaruhi motivasi, prestasi, dan kepuasan kerja. Iklim mempengaruhi hal itu dengan membentuk harapan pegawai tentangkonsekuensi yang akan timbul dari berbagai tindakan." ${ }^{22}$. Bahkan disebutkan bahwa lingkungan kerja yang kurang mendukung sepertilingkungan fisik pekerjaan dan hubungan kurang serasi antar guru ikutmenyebabkan kinerja menjadi buruk.

Secara kuantitatif, variableiklim organisasi dan motivasi kerja merupakan suatu hal yang memiliki keterkaitan antara yang satu dengan yang lainnya. Sebutan Madrasah berperestasi telah ikut andil dalam menumbuhkembangkan iklim organisasi dan meningkatkan motivasi kerja guru. Ada beban moral dan psikologis bagi mereka untuk terus meningkatkan kompetensi diri dalam mendukung terciptanya Madrasah berkualitas.Menurut Lyman Porter dan Raymond Miles ${ }^{23}$ bahwa ada tiga faktor utama yang berpengaruh terhadap motivasi kerja, salah satunya yaitu lingkungan kerja (work situation characteristic). Dengan demikian, semakin baik dan kondusif iklim organisasi madrasah maka semakin meningkat motivasi kerja guru. Ada rasa nyaman untuk berkereasi dan bekerja maksimal dalam sebuah lingkungan yang mendukung kerja mereka. Sebaliknya sebuah lingkungan yang tidak nyaman, penuh tekanan dan tidak kondusif cendrung akan melahirkan sumber daya manusia yang apatis dan mandul prestasi bahkan menjadi pemalas. Karena itu, iklim organisasi bagi suatu organisasi madrasah, maka sistem yang sudah ada harus mampu mendorong atau memotivasi kerja bagi para gurunya. Dalam arti dimana iklim organisasi yang mendorong terciptanya motivasi kerja guru harus terus ditingkatkan. Kerjasama antara pimpinan dan bawahan harus tetap terjalin dengan baik, tanpa adanya kerjasama yang baik maka tidak mustahil iklim organisasi yang sudah melekat dengan baik akan menjadi tidak sesuai dengan yang diharapkan untuk mencapai tujuan organisasi tersebut.

\section{Kesimpulan}

Kesimpulan dari penelitian ini adalah iklim Madrasah [organisasi] yang sehat,ditandai dengan berjalannya secara maksimal aspek pengendalian, adanya kepemimpinan yang demokratis, terjalinnya komunikasi dan intraksi antar personal secara terbuka dan kekeluargaan serta penetapan tujuan organisasi dilakukan melalui keputusan secara bersama, akan menumbuhkan motivasi kerja guru yang kuat ditunjukkan dengan disiplin tinggi, semangat untuk bekerja, memiliki sikap kompetisi yang sehat, dan suka berkeja kerasdalam melaksanakan tugas dan perannya dan pada gilirannya akan meningkatkan mutu pendidikan di Madrasah itu sendiri. Selain itu, pengakuan outsider terhadap Madrasah sebagai lembaga pendidikan Islam [Madrasah Tsanawiyah model] berperan dalam menjaga stabilitas iklim

\footnotetext{
${ }^{22}$ Keith Davis dan John W, Newstrom (1996: 23)

${ }^{23}$ Lyman Porter dan Raymond Miles dalam Wahjosumidjo. (1992). Kepemimpinan dan Motivasi. Jakarta: Bumi Aksara.
} 
organisasi yang mempengaruhi spirit para guru untuk terus menjaga dan meningkatkan kinerja mereka.

\section{Daftar Pustaka}

Azyumardi Azra, 2002. Pendidikan Islam, Tradisi dan Modernisasi Menuju Milenium Baru, (Jakarta :Logos Wacana Ilmu).

Burhan Bungin, (2008), Penelitian Kualitatif, (Jakarta: Kencana Prenada Media Group)

Cumbey and Alexander, 1998. The relationship of job satisfaction with organizational variables in public health nursing. Journal of Nursing Administration, 28

Davis, Keith \& W. Newstrom, Jhon. (1985). Perilaku dalam Organisasi. Jakarta :Erlangga.

Giddens, Anthony (1984), The Constitution of Society; Outline of the Theory of Structuration (Berkley: University of California Press), hlm. xxxiii

Ghony, Djunaidi M \& Almanshur, Fauzan (2012), Metode Penelitian Kualitatif, (Yogyakarta: Ar-Ruzz Media)

George R Terry, 2006. Prinsip-prinsip Manajemen, Bumi Aksara, Jakarta, Giddens, Anthony (1984), The Constitution of Society; Outline of the Theory of Structuration (Berkley: University of California Press),

Hasibuan, M. (1995). Manajemen Sumber Daya Manusia. Jakarta: PT Gunung Agung.

Hasibuan, M. (2001). Organisasi dan Motivasi. Jakarta: Bumi Aksara.

Jones and James, 1979. Psychological climate: dimensions and relationships of individual and aggregate work environment perceptions. Organizational Behavior and Human Performance, 23

Mujib, Abdul, Mudzakir,Jusuf, 2006. Ilmu Pendidikan Islam, Cet. I, Jakarta: Kencana Prenada Media

Nata, A. (2010). Manajemen Pendidikan Mengatasi Kelemahan Pendidikan Islam di Indonesia. Jakarta: Kencana.

Nurdin, Asep (2005). Kontribusi Kompensasi dan Iklim Organisasi Sekolah terhadap Kinerja Guru (Kajian Terhadap Guru SMP Di KabupatenBandung). Tesis (Tidak Dipublikasikan). Bandung. PPS UPI.

Robbins, Stephen P. (1994). Teori Organisasi (struktur, Desain dan Aplikasi). Edisi Ketiga. Jakarta: Arca

Soltani, I., Aghahosseini, M., \& Akbari, N. (2014). Employees' perspective on organizational climate and job motivation factors and their relationship with the Blood Transfusion Organization's employees, 2012. International Journal of Academic Research in Business and Social Sciences, 4

Steers, Richard M. (1985). Efektifivas Organisasi. Cetakan Kedua. Jakarta: Erlangga

Supardi dan Saiful Anwar. (2002). Dasar-dasar Perilaku Organisasi. Yogyakarta: 
UII Press.

Thoha, Miftah.(2002). Perilaku Organisasi. Jakarta: Raja Grafindo Persada

Tovey and Adams, 1999. The changing nature of nurses' job satisfaction: an exploration of sources of satisfaction in the 1990s. Journal of Advanced Nursing, 30

Undang-Undang Sistem Pendidikan Nasional Nomor 20 Tahun 2003 tentang Sistem Pendidikan Nasional pasal 1 ayat 1.

Yoo, S. J., Huang, W.-H., \& Lee, D. Y. (2012). The impact of employee's perception of organizational climate on their technology acceptance toward e-learning in South Korea. Knowledge Management \& E-Learning: An International Journal (KM\&EL), 4(3), 359-378. Zhang, J., \& Liu, Y. (2010). Organizational climate and its effects on organizational variables: An empirical study. International Journal of Psychological Studies, 2(2)

Wahjosumidjo. (1992). Kepemimpinan dan Motivasi. Jakarta: Bumi Aksara. 